\title{
TRPA1 wt Allele
}

National Cancer Institute

\section{Source}

National Cancer Institute. TRPA1 wt Allele. NCI Thesaurus. Code C153284.

Human TRPA1 wild-type allele is located in the vicinity of $8 \mathrm{q} 21.11$ and is approximately 70 $\mathrm{kb}$ in length. This allele, which encodes transient receptor potential cation channel subfamily A member 1 protein, is involved in cation transport and pain responses. Mutation of the gene is associated with familial episodic pain syndrome type 1. 